\title{
Are Female Accountants More Ethical Than Male Accountants: A Comparative Study Between The U.S. And Taiwan
}

Chiulien Chuang Venezia, Frostburg State University

\begin{abstract}
The purpose of this study is to determine and compare the ethical reasoning levels of accounting students in the U.S. and Taiwan based on gender. This research found that female accounting students possess higher levels of ethical reasoning than male students. The means of the DIT P and N2 scores for females are higher than males by $20 \%$ and $18.5 \%$ respectively. The results show that there is no significant difference of the ethical reasoning abilities of male accounting students between the U.S. and Taiwan. The results also show that there is no significant difference between the ethical reasoning levels of female accounting students in Taiwan and the ethical reasoning levels of female accounting students in the U.S.
\end{abstract}

Keywords: DIT, gender, accounting, ethical reasoning

\section{INTRODUCTION}

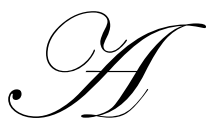

ccounting professionals have an obligation to present truthful financial reports to the public, their profession, and the organizations they serve. Auditors have a responsibility to evaluate and validate other accountants' reports. However, the accounting profession may face ethical dilemmas when it proceeds with these and other tasks.

There are several codes or standards of ethics that have been developed to guide accountants in performing their duties. The accounting profession's ethical standards can be found in the rules and regulations of the American Institute of Certified Public Accountants (AICPA), state accounting societies, the Securities and Exchange Commission (SEC), the General Accounting Office, Public Company Accounting Oversight Board, and the Institute of Management Accountants (IMA) in the United States.

The Code of Professional Conduct of AICPA and Standards of ethical conduct for practitioners of management accounting and financial management of IMA are the two major standards for the accounting profession (Duska \& Duska, 2003).

The Code of Professional Conduct of the AICPA consists of four major sections: the Principles, the Rules, Interpretations of Rules, and Ethics Rulings. The Principles provide the framework for the Rules, which govern the performance of professional services by members. Interpretations of Rules provide guidelines as to the scope and application of the Rules. Ethics Rulings consist of formal rulings. These rulings summarize the application of Rules of Conduct and Interpretations to a particular set of factual circumstances (AICPA, 2007).

The Code of Professional Conduct of the Republic of China, which is the formal name of Taiwan, Certified Public Accountants (ROCCPA), was established in 1970, and recently revised in March 2003. The Code is composed of five main sections: Principles, the Profession Rules, the Technical Rules, Advertising, and Performing Duties (ROCCPA, 2007). 
Similarities between the U.S. and Taiwan codes include requiring members to be independent and objective and maintain integrity in the performance of their professional services, as well as prohibiting them from disclosing confidential information. The basic differences between the two countries' codes are illustrated by: the American code prohibiting its members from performing any audits or reviews for a contingent fee. The ROCCPA code of Taiwan does not mention the issue of contingent fees; however, it states that service fees should refer to a set fee regulated by the ROCCPA on a sliding scale in relation to a company's revenues. The AICPA code prohibits false, misleading, and deceptive advertising. The ROCCPA code states the same as the AICPCA code concerning advertising, as well as addressing the prohibition of soliciting clients through bribery or implying guanxi. Guanxi is a long-term relationship built over one's lifetime, differing from the western quid pro quo, which is a common business practice in Asia, especially in Chinese society.

The major difference is the form of practice and name. Prior to 1994, the U.S. code required that all owners of an accounting firm must be CPAs; however, after 1994 the code was revised. It allows non-CPAs to have ownership in an accounting firm when the CPA partners have the majority of the firm's financial interest and voting rights. In Taiwan, the code does not allow non-CPAs to join in a partnership.

\section{Western Ethics}

Socrates, Plato, and Aristotle are the foundation of Western thinking. Their ethics are grounded in the knowledge and choice of the good things in life. The knowledge of virtue is acquired through continuous search and questioning about things and action (Makrydemetres, 2001).

\section{Chinese Ethics}

During the Sixth century B.C., the Chinese developed two different philosophical schools, Taoism (or Daoism) and Confucianism. Taoism was concerned with observing nature and the discovery of its way, referred to as Tao. Confucianism was the philosophy of social organization, of common sense, and practical knowledge. One of Confucianism's main purposes was to form an ethical basis for the traditional Chinese family system (Capra, 1976, p.92). Both Taoism and Confucianism influenced Chinese life and thought.

\section{LITERATURE REVIEW}

\section{Cognitive And Moral Development}

Piaget

Jean Piaget was among the first psychologists whose work remains directly relevant to contemporary theories of moral development. In the Moral Judgment of the Child (Piaget, 1965), he focused on the moral development of children. He observed the way children played games to discover how children of differing ages understood the rules for the game. He also interviewed children regarding the act of stealing and lying to investigate how a child reacts in relation to moral judgments. He argued that children develop morally from heteronomy to autonomy and to equity. Piaget developed a framework, which he described as stages in conceptualization, on the consciousness of rules present in children and young adults during the development of their moral judgment (Ponemon, 1990).

\section{Kohlberg}

Kohlberg modified Piaget's work; Kohlberg stated that moral issues continue to develop throughout adolescence. Kohlberg, therefore, interviewed both children and adolescents about moral dilemmas to investigate how they develop a sense of right, wrong, and justice; he found stages that go well beyond Piaget's. He developed six stages, only the first three share features with Piaget's stages (Crain, 1980). 
Kohlberg's (1984, p.174) six stages of Moral Judgment Development are:

Level I: Pre-conventional Morality

Stage 1: Heteronomous Morality

Stage 2: Individualism, Instrumental Purpose, and Exchange

Level II: Conventional Morality

Stage 3: Mutual Interpersonal Expectations, Relationships and Interpersonal Conformity

Stage 4: Social System and Conscience

Level III: Post-conventional Morality

Stage 5: Social Contract or Utility and Individual Rights

Stage 6: Universal Ethical Principles

Rest

Based on Kohlberg's theory, James Rest developed a revision of the developmental process of moral judgment-Defining Issues Test. Rest's model of moral judgment differs from Kohlberg's in several important ways (Rest, 1979). "For the measurement of moral reasoning, Rest's model assesses an individual's tendency to use concepts of justice based on social cooperation in his or her moral thinking, while Kohlberg's model assesses an individual's use of justice concepts, focusing more on exchange and individual interests" (Elm and Weber, 1994, p. 346).

It has been 30 years since the Defining Issues Test (DIT) was designed (Rest et al., 1974). DIT has been used in accounting and other areas to measure ethical reasoning ability. Many researchers found that gender, education, age, and taking ethics courses may affect moral reasoning abilities (Ponemon and Glazer, 1990; Armstrong, 1993; Shaub, 1994; Jones and Hiltebeitel, 1995; and Elm et al., 2001). However, some studies showed that there is no significant relationship (Ma and Chan, 1987; Thorne \& Magnan, 2000; Roger \& Smith, 2001). Country comparisons have been studied; however, most research compared western countries, (Ponemon \& Gabhart, 1993; Husted et al., 1996; Hill et al., 1998; Thorne et al., 2003), with few comparisons between Asia and Western countries (Ma, 1988b; Tsui, 1996; Tsui \& Windsor, 2001; Kracher et al., 2002).

\section{Gender Issues}

The results from previous research indicated that gender might affect moral reasoning. Females have demostrated higher levels of moral reasoning ability than males (St. Pierre et al., 1990; Shaub, 1994; Sweeny, 1995; Bernardi \& Arnold. 1997; Cohen et al., 1998; Elm et al., 2001). However, some researchers stated that gender has no significant effect on moral reasoning (Ma \& Chan, 1987; Armstrong, 1987; Ponemon, 1992; Teal \& Carroll, 1999; Thorne \& Magnan, 2000; Rogers \& Smith, 2001, Abdolmohammadi et al. 2003).

St. Pierre et al. (1990) studied the ethical development among American students. They surveyed 479 senior students in ten majors; including 59 in finance, 19 in Hotel/Restaurant management, 61 in information systems, 21 in international business, 71 in management, 69 in marketing, 81 in psychology, 17 in social work, 12 in math, and 69 accounting students at one medium sized state university. The results showed that female accounting students' mean P score to be 45.84 and the mean P score for males 38.57. The other nine majors' female students' mean P scores were also higher than males'. Over all, accounting students' mean P score was in the fifth highest rank of the ten majors. The authors stated there are significant differences in DIT scores of males and females.

Shaub (1994) investigated the relationship of demographic variables with the moral reasoning of accounting students and auditors. He collected the data from 207 auditors from four offices of a single Big-Six CPA firm in the southwestern United States and 91 senior accounting students from a mid-western university. The threescenario DIT survey was used to get a higher response rate. His findings showed that at a significant 0.05 level females had a significantly higher level of moral reasoning than males in both samples. 
Bernardi and Arnold (1997) surveyed 494 auditors from five of the Big Six accounting firms in the U.S. The DIT short form was used to measure the moral development. Their findings showed that female accountants' average level of moral development is higher than males.

Cohen et al. (1998) tested gender and discipline effects on ethical judgment. The subjects were accounting, business, and liberal art undergraduate students from four universities in the northeastern United States. The results showed that females posses higher level of ethical reasoning. The authors stated that gender affected moral development.

However, Ma and Chan (1987) argued that there is no significant gender difference in all of the stage scores derived from DIT ratings and ranking. The authors surveyed 168 Chinese students from grade 9 to graduate level university students in Hong Kong. The results indicated that the mean P score for males and females was 30.06 and 30.82, respectively. The authors concluded that there were no significant gender differences in all the DIT rating or ranking stage scores.

Rogers and Smith (2001) examined the gender and age effects on ethical reasoning. The data was collected from 88 accounting students at a state university in the southern United States, using a three-scenario DIT survey and unethical vignettes. The results indicated that there is no significant gender difference.

Abdolmohammadi et al. (2003) indicated that the mean P-scores (44.8 for women and 43.5 for men) were not significantly different between female and male staff accountants.

\section{METHDOLOGY}

The purpose of this study is to determine and compare the ethical reasoning levels of accounting students in the U.S. and Taiwan based on gender. gender?

Do accounting students demonstrate significant difference in their responses to ethical dilemmas based on

\section{Research Question:}

Is there a difference in the level of ethical reasoning of male accounting students and female accounting students?

\section{Research Hypotheses:}

H01: The ethical reasoning levels of male accounting students are not different than the ethical reasoning levels of female accounting students.

H02: The ethical reasoning levels of male accounting students in Taiwan are not different than the ethical reasoning levels of male accounting students in the U.S.

H03: The ethical reasoning levels of female accounting students in Taiwan are not different than the ethical reasoning levels of female accounting students in the U.S.

\section{Test Instrument}

This study uses the new version of the DIT (DIT-2), developed by Rest, and a demographic questionnaire for students whose major is accounting.

The DIT instruments were acquired from the Center for the Study of Ethical Development at University of Minnesota. The DIT-2 (N2) scores were scored by The Center's Scoring Service. 
The underlying structure of moral judgment assessed by the DIT consists of three developmental schemas: personal interest, maintaining norms, and post-conventional (Rest et al., 1999a). The complete DIT-2 consists of five dilemmas. The five dilemmas of DIT-2 are:(a) famine: a father contemplates stealing food for his starving family from the warehouse of a rich man hoarding food; (b) reporter: a newspaper reporter must decide whether to report a damaging story about a political candidate; (c) school board: a school board chair must decide whether to hold a contentious and dangerous open meeting; (d) cancer: a doctor must decide whether to give an overdose of pain-killer to a suffering but frail patient; (e) demonstration: college students demonstrate against U.S. foreign policy. Each story contains three sections of participants' responses. First, participants are asked whether they favor the action of the decision of the story. Second, participants are asked to rate the twelve issues in terms of importance. In the third section, participants are asked to rank the four most important issues of the 12 issues of each story. On the last page of the DIT-2 answer sheet the participant was asked to answer demographic questions.

\section{Test Instrument Validity And Reliability}

There are over 800 studies using the DIT survey to measure moral reasoning; there are over 400 published articles and books on the DIT (Rest et al, 1999a). The fact that the DIT has been continuously used for 25 years in different groups for the study of ethical development shows that the DIT survey is a valid instrument.

Rest et al, (1999b) showed that the Cronbach Alphas of P and N2 indexes are as follows: P index is 0.76 and N2 index is 0.80 in 994 composite sample in 1979 and $\mathrm{P}$ index is 0.78 and $\mathrm{N} 2$ index is 0.83 in 932 composite sample in 1995. Both indexes show the reliability of the instrument. The N2 has a slightly higher Cronbach Alphas than the P index.

The Analysis of the Variance (ANOVA) statistic analysis will be used to identify the differences in the means of researched variables.

\section{The Mandarin Chinese Version Of DIT-2}

This author translated the DIT-2 from English to Mandarin Chinese. A bilingual professor at Nova Southeastern University validated the author's translation. A professor at the Applied English Department of Southern Taiwan University of Technology in Tainan, Taiwan translated the Chinese version of the DIT-2 back into English. The Chairman of the Accounting Information Department at Southern Taiwan University of Technology validated the Chinese version of the DIT-2 with the translated English version to substantiate the original meaning. The Chinese version of the DIT-2, which included the DIT-2 instructions, five stories, answer sheets, and demographic questions, was used with Taiwanese participants.

\section{Data Collection}

One hundred fourteen participants of the U.S. completed the surveys, and 118 Taiwanese participants completed the surveys. Two hundred thirty-two surveys were mailed to the Center for the study of Ethical Development at the University of Minnesota for scoring.

\section{Reliability Checks}

The Center purged 29 surveys from the U.S. group and 4 from the Taiwan group because of "bogus" data or the failure of the reliability check. A total of 33 surveys, which composed $14 \%$ of completed surveys, were purged from the analysis. Of the U.S. students' surveys, 13 surveys were eliminated from the analysis because they were not Accounting major students. A total of 72 surveys from the U.S. samples, and 116 surveys from Taiwan samples were used in this research.

Table 1: Demographic Information

\begin{tabular}{|cl|c|c|c|}
\hline & U.S. group & Taiwan group & Total \\
\hline Gender & Female & 30 & 102 & 132 \\
& Male & 42 & 14 & 56 \\
Total N= & 72 & 116 & 188 \\
\hline
\end{tabular}




\section{ANALYSIS RESULTS}

The mean N2 and P scores on the Defining Issues Test indicated the students' ethical reasoning abilities or level of moral maturity. Each of the hypotheses is examined; the observed significance level (or p value) is at 0.05 .

\section{Hypothesis 1:}

The ethical reasoning levels of male accounting students are not different than the ethical reasoning levels of female accounting students.

The findings (Table 2) show that mean $\mathrm{P}$ score are 26.41 for males and 31.74 for female accounting students. The mean N2 scores are 26.23 for males and 31.08 for female accounting students.

Table 2: DIT-2 Scores Descriptive Statistics by Gender

\begin{tabular}{|c|c|c|c|}
\hline \multicolumn{4}{|c|}{ Report } \\
\hline \multicolumn{2}{|l|}{ SEX } & $\begin{array}{c}\text { Post } \\
\text { Conventional } \\
\text { (P score) }\end{array}$ & NZSOORE \\
\hline \multirow{3}{*}{ male } & Mean & 26.4091 & 26.2269 \\
\hline & $\mathbf{N}$ & 56 & 56 \\
\hline & Std. Deviation & 12.4186 & 12.6657 \\
\hline \multirow[t]{3}{*}{ female } & Mean & 31.7353 & 31.0778 \\
\hline & $\mathbf{N}$ & 132 & 132 \\
\hline & Std. Deviation & 11.5243 & 11.5411 \\
\hline \multirow[t]{3}{*}{ Total } & Mean & 30.1488 & 29.6329 \\
\hline & $\mathbf{N}$ & 188 & 188 \\
\hline & Std. Deviation & 12.0151 & 12.0598 \\
\hline
\end{tabular}

A one-way ANOVA (Table 3) results in the null hypothesis being rejected when applying N2 score $\left(F_{(1,186)}=6.55, p=0.011\right)$ and $P$ score $\left(F_{(1,186)}=8.017, p=0.005\right)$. There is a significant difference between male and female accounting students. Female accounting students have significantly higher N2 and P scores than males.

Table 3: DIT-2 Scores ANOVA by Gender

ANOVA

\begin{tabular}{|ll|r|r|r|r|r|}
\hline & & \multicolumn{1}{|c|}{ Sum of } & & & \\
\hline Post Conventional & Setween Groups & 1115.428 & df & Mean Square & F & Sig. \\
(P score) & Within Groups & 25880.238 & 186 & 1115.428 & 8.017 & .005 \\
& Total & 26995.666 & 187 & 139.141 & & \\
\hline N2SCORE & Between Groups & 925.227 & 1 & 925.227 & 6.550 & .011 \\
& Within Groups & 26271.916 & 186 & 141.247 & & \\
& Total & 27197.144 & 187 & & & \\
\hline
\end{tabular}

\section{Hypothesis 2:}

The ethical reasoning levels of male accounting students in Taiwan are not different than the ethical reasoning levels of male accounting students in the U.S. 
The mean $\mathrm{P}$ scores are 26.59 for the U.S. male accounting students and 25.86 for Taiwanese male accounting students (Table 4). The mean N2 scores are 26.67 for the U.S. male accounting students and 24.91 for male Taiwanese accounting students.

Table 4 DIT-2 Scores Descriptive Statistics by Country (Male)

Report

\begin{tabular}{|ll|r|r|}
\hline COUNTRY & $\begin{array}{r}\text { Post } \\
\text { Conventional } \\
(P \text { score })\end{array}$ & N2SCORET \\
\hline USA & Mean & 26.5931 & 26.6658 \\
& $N$ & 42 & 42 \\
& Std. Dev iation & 12.6960 & 12.3982 \\
\hline TAIWAN & Mean & 25.8571 & 24.9103 \\
& N & 14 & 14 \\
& Std. Dev iation & 11.9863 & 13.8353 \\
\hline Total & Mean & 26.4091 & 26.2269 \\
& N & 56 & 56 \\
& Std. Dev iation & 12.4186 & 12.6657 \\
\hline
\end{tabular}

The null hypothesis is not rejected. An ANOVA (Table 5) results show that there is no significant difference of the ethical reasoning abilities of male accounting students between the U.S. and Taiwan. (P score,

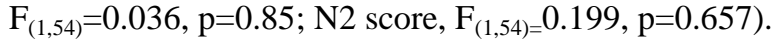

Table 5 DIT-2 Scores ANOVA by Country (Male)

ANOVA

\begin{tabular}{|ll|r|r|r|r|r|}
\hline & & \multicolumn{1}{c|}{$\begin{array}{c}\text { Sum of } \\
\text { Squares }\end{array}$} & df & Mean Square & F & Sig. \\
\hline Post Conventional & Between Groups & 5.686 & 1 & 5.686 & .036 & .850 \\
(P score) & Within Groups & 8476.461 & 54 & 156.972 & & \\
& Total & 8482.147 & 55 & & & \\
\hline N2SCORET & Between Groups & 32.361 & 1 & 32.361 & .199 & .657 \\
& Within Groups & 8790.674 & 54 & 162.790 & & \\
& Total & 8823.035 & 55 & & & \\
\hline
\end{tabular}

\section{Hypothesis 3:}

The ethical reasoning levels of female accounting students in Taiwan are not different than the ethical reasoning levels of female accounting students in the U.S.

The mean P scores are 29.52 for the U.S. and 32.39 for Taiwanese female accounting students. The mean N2 scores are 27.91 for U.S. females and 32.01 for Taiwanese female accounting students. 
Table 6 DIT-2 Scores Descriptive Statistics by Country (Female)

\begin{tabular}{|ll|r|r|}
\multicolumn{5}{|c|}{ Report } \\
\hline COUNTRY & $\begin{array}{c}\text { Post } \\
\text { Conventional } \\
(P \text { score })\end{array}$ & N2SCORET \\
\hline USA & Mean & 29.5167 & 27.9131 \\
& N & 30 & 30 \\
& Std. Dev iation & 12.2605 & 13.3224 \\
\hline TAIWAN & Mean & 32.3878 & 32.0086 \\
& N & 102 & 102 \\
& Std. Dev iation & 11.2785 & 10.8605 \\
\hline Total & Mean & 31.7353 & 31.0778 \\
& N & 132 & 132 \\
& Std. Dev iation & 11.5243 & 11.5411 \\
\hline
\end{tabular}

An ANOVA fails to reject the null hypothesis. There is no significant difference between the ethical reasoning levels of female accounting students in Taiwan and the ethical reasoning levels of female accounting

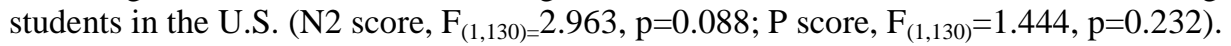

Table 7 DIT-2 Scores ANOVA by Country (Female)

ANOVA

\begin{tabular}{|ll|r|r|r|r|r|}
\hline & & \multicolumn{1}{|c|}{$\begin{array}{c}\text { Sum of } \\
\text { Squares }\end{array}$} & df & Mean Square & F & Sig. \\
\hline Post Conventional & Between Groups & 191.101 & 1 & 191.101 & 1.444 & .232 \\
(P score) & Within Groups & 17206.990 & 130 & 132.361 & & \\
& Total & 17398.090 & 131 & & & \\
\hline N2SCORET & Between Groups & 388.829 & 1 & 388.829 & 2.963 & .088 \\
& Within Groups & 17060.052 & 130 & 131.231 & & \\
& Total & 17448.881 & 131 & & & \\
\hline
\end{tabular}

\section{DISCUSSION AND CONCLUSION}

This research found that female accounting students possess higher levels of ethical reasoning than male accounting students. The means of the DIT P and N2 scores for females are higher than males by $20 \%$ and $18.5 \%$ respectively.

Similar to the finding of Cohen et al. (1998), this author's findings indicate that females have higher ethical reasoning abilities than males. According to Gilligan's (1982) study, the difference in ethical reasoning by female and male could be that females are more caring and supportive of the needs of other people, i.e., oriented towards nurturing, than males.

There are some limitations of this research. First, as to the relationship between the ethical reasoning of a person, and how a person actually reacts to ethics dilemmas, may be different. It is difficult to evaluate the influence of the ethical reasoning abilities on accounting students' ethical behavior. 
The second limitation of this study is that the research findings are based on accounting students from only one university in Taiwan. The sample of this study thus may not represent the population of accounting students. However, the $\mathrm{P}$ scores of this research are similar to prior research using accounting students as samples. This fact increases the reliability of the small sample results. this study.

Further study may compare the two countries using more universities to see if there is a different result than

This study will help multinational companies and accounting firms to understand better that gender may affect the moral maturity and ethical reasoning of their accounting employees. Accordingly, these firms as well as the accounting profession may need to design different recruiting and training systems to ensure that future accountants possess moral maturity and ethical reasoning capabilities.

\section{REFERENCES}

1. Abdolmohammadi, M.J., Read, W.J., and Scarbrough, D.P. (2003). Does Selection-Socialization Help to Explain Accountants' Weak Ethical Reasoning? Journal of Business Ethics. 42,1, 71-81.

2. AICPA, (2007). Code of Professional Conduct. Retrieved from AICPA website: www.aicpa.org.

3. Armstrong, M.B., (1987). Moral development and accounting education. Journal of Accounting Education, 5(1), 27-43.

4. Armstrong, M.B., (1993). Ethics and professionalism in Accounting education: A sample course. Journal of Accounting Education, 11, 77-92.

5. Bernardi, R. and Arnold, D.,(1997). An examination of moral development within public accounting by gender, staff level, and firm. Contemporary Accounting Research, 14(4), 653-668.

6. $\quad$ Capra, F. , ( 1976). The Tao of Physics. NY: Bantam Books.

7. Cohen, J.R., Pant, L.W. and Sharp, D.J., (1998). The Effect of Gender and Academic Discipline Diversity on the Ethical Evaluations, Ethical Intentions and Ethical Orientation of Potential Public Accounting Recruits. Accounting Horizons, 12(3), 250-270.

8. Crain, W.C., (1980). Theories of Development: Concepts and Applications. Englewood Cliffs, NJ: Prentice-Hall, Inc.

9. $\quad$ Duska, R.E. and Duska, B.S., (2003). Accounting Ethics. Malden, MD: Blackwell.

10. Elm, D.R., Kennedy, E.J., and Lawton, L., (2001). Determinants of Moral Reasoning: Sex Role Orientation, Gender, and Academic Factors. Business and Society, 40(3), 241-265.

11. Elm, D.R. and Weber, J., (1994). Measuring Moral Judgment: The Moral Judgment Interview or the Defining Issues Test? Journal of Business Ethics, 13(5), 341-355.

12. Gilligan, C. (1982). In a Difference Voice: Psychological Theory and Women's Development. Cambridge, MA: Harvard University Press.

13. Hill, N., Stevens, K. and Clarke, P., (1998). Factors that affect ethical reasoning abilities of U.S. and Irish small firm accounting practitioners. Research of Accounting Ethics, 4, 145-166.

14. Husted, B.W., Dozier, J.B., McMahon, J.T. and Kattan, M.W., (1996). The impact of cross-national carriers of business ethics on attitudes about questionable practices and form of moral reasoning. Journal of International Business Studies, 2,391-411.

15. Jones, S.K. and Hiltebeitel, K.M., (1995). Organizational Influence in a Model of the Moral Decision Process of Accountants. Journal of Business Ethics, 14(6), 417-431.

16. Kohlberg, L., (1984). Essays on Moral Development: Volume II. The Psychology of Moral Development: The Nature and Validity of Moral Stages. San Francisco: Horper \& Row.

17. Kracher, B., Chatterjee, A. and Lundquist, A.R., (2002). Factors Related to the Cognitive Moral Development of Business Students and Business Professionals in India and the United States: Nationality, Education, Sex and Gender. Journal of Business Ethics, 34(4), 255-268.

18. Ma, H.K., (1988a). The Chinese perspectives on moral judgment development. International Journal of psychology, 23, 201-227.

19. Ma, H.K. (1988b). Objective Moral Judgement in Hong Kong, Mainland China, and England. Journal of Cross-Cultural Psychology, 19(1), 78-95. 
20. Ma, H.K. and Chan, W.S., (1987). The Moral Judgments of Chinese Students. The Journal of Social Psychology, 127(5), 491-497.

21. Makrydemetres, A. (2001). The “ALIR" imperatives of ethical reasoning. Global Virtue Ethics Review, July, 180-198.

22. Piaget, J., (1965). The Moral Judgment of the Child. NY: The Free Press.

23. Ponemon, L.A., (1990). Ethical Judgment in Accounting: A Cognitive-Developmental Perspective. Critical Perspectives on Accounting, 1, 191-215.

24. Ponemon, L.A., (1992). Ethical reasoning and selection-socialization in accounting. Accounting Organization and Society, 17(3/4), 239-258.

25. Ponemon, L.A. and Gabhart, D.R.L., (1993). Ethics Reasoning in Accounting and Auditing. Vancouver : CGA-Canada Research Foundation.

26. Ponemon, L.A. and Glazer A., (1990). Accounting education and ethical development: The influence of liberal learning on students and alumni in accounting practice. Issues in Accounting Education, 5, 195-208.

27. Rest, J.R., (1979). Development in Judging Moral Issues. Minneapolis, NM: University of Minnesota Press.

28. Rest, J., Cooper, D., Coder, R., Masanz, J., and Anderson, D., (1974). Judging the important issues in moral dilemmas-An objective test of development. Developmental Psychology, 10, 491-501.

29. Rest, J.R., Narvaez, D., Thoma, S.J. and Bebeau, M.J., (1999a). DIT2 Devising and Testing a Revised Instrument of Moral Judgment. Journal of Educational Psychology, 91(4), 644-659.

30. Rest, J.R., Narvaez, D., Bebeau, M.J. and Thomas, S.J., (1999b). Postconventional Moral Thinking: A NeoKohlbergian Approach. Mahwah, NJ: Lawrence Erlbaum.

31. ROCCPA, (2007). Code of Professional Conduct. Retrieved from ROCCPA website: www.roccpa.org.

32. Rogers, V. and Smith, A., (2001). Ethics, Moral Development, and Accountants-in-Training. Teaching Business Ethics, 5(1), 1-20.

33. Shaub, M.K., (1994). An analysis of the association of traditional demographic variables with the moral reasoning of auditing students and auditors. Journal of Accounting Education, 12(1), 1-26.

34. St Pierre, K., Nelson, E. and Gabbin, A., (1990). A study of the ethical development of accounting majors in relation to other business and nonbusiness disciplines. The Accounting Educator's Journal, summer, 2335 .

35. Sweeny, J., (1995). The ethical expertise of accountants: An exploratory analysis. Research on Accounting Ethics, 1, 213-234.

36. Teal, E. J. and Carroll, A.B., (1999). Moral reasoning skills: Are entreprenerurs differenct? Journal of Business Ethics, 19(3), 229-240.

37. Thorne, L. (2000). The development of context-specific measures of accountants' ethical reasoning. Behavioral Research in Accounting, 12, 139-170.

38. Thorne, L., \& Magnan, M. (2000). Canadian public accountant moral development and domain specific reasoning. Research on Accounting Ethics, 7, 177-196.

39. Thorne, L., Massey, D. and Magnan, M., (2003). Institutional context and auditors' moral reasoning: a Canada-USA comparison. Journal of Business Ethics, 43(4), 305-321.

40. Tsui, J.S.L., (1996). Auditors' Ethical Reasoning: Some audit Conflictand Cross Cultural Evidence. The International Journal of Accounting, 31(1), 121-133.

41. Tsui, J.S.L. and Windsor, C., (2001). Some cross-cultural evidence on ethical reasoning. Journal of Business Ethics, 31(2), 143-150. 